\title{
Reading Matthew 13 as a prophetic discourse: The four parables presented in public
}

\begin{tabular}{|c|c|}
\hline \multicolumn{2}{|c|}{$\begin{array}{l}\text { Author: } \\
\text { Jacob J. Scholtz }{ }^{1}\end{array}$} \\
\hline \multicolumn{2}{|c|}{$\begin{array}{l}\text { Affiliation: } \\
{ }^{1} \text { Discipline Group Old and } \\
\text { New Testament, Faculty } \\
\text { of Theology, Stellenbosch } \\
\text { University, South Africa }\end{array}$} \\
\hline \multicolumn{2}{|c|}{$\begin{array}{l}\text { Correspondence to: } \\
\text { Jacob Scholtz }\end{array}$} \\
\hline \multicolumn{2}{|c|}{$\begin{array}{l}\text { Email: } \\
\text { jacojanscholtz@gmail.com }\end{array}$} \\
\hline \multicolumn{2}{|c|}{$\begin{array}{l}\text { Postal address: } \\
14 \text { Botrivier Street, } \\
\text { Protea Valley, Bellville 7530, } \\
\text { South Africa }\end{array}$} \\
\hline \multicolumn{2}{|c|}{$\begin{array}{l}\text { Dates: } \\
\text { Received: } 04 \text { Aug. } 2014 \\
\text { Accepted: } 13 \text { Feb. } 2015 \\
\text { Published: } 20 \text { Apr. } 2015\end{array}$} \\
\hline \multicolumn{2}{|c|}{$\begin{array}{l}\text { How to cite this article: } \\
\text { Scholtz, J.J., 2015, 'Reading } \\
\text { Matthew } 13 \text { as a prophetic } \\
\text { discourse: The four parables } \\
\text { presented in public', In die } \\
\text { Skriflig } 49(1) \text {, Art. \#1870, } \\
7 \text { pages. http://dx.doi. } \\
\text { org/10.4102/ids.v49i1.1870 }\end{array}$} \\
\hline \multicolumn{2}{|c|}{$\begin{array}{l}\text { Note: } \\
\text { This article is based on a } \\
\text { study at the Stellenbosch } \\
\text { University (Discipline Group } \\
\text { Old and New Testament, } \\
\text { Faculty of Theology). }\end{array}$} \\
\hline \multicolumn{2}{|c|}{$\begin{array}{l}\text { Copyright: } \\
\text { (C) 2015. The Authors. } \\
\text { Licensee: AOSIS } \\
\text { OpenJournals. This work is } \\
\text { licensed under the Creative } \\
\text { Commons Attribution } \\
\text { License. }\end{array}$} \\
\hline \multicolumn{2}{|c|}{ Read online: } \\
\hline 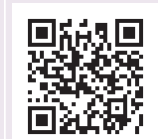 & $\begin{array}{l}\text { Scan this QR } \\
\text { code with your } \\
\text { smart phone or } \\
\text { mobile device } \\
\text { to read online. }\end{array}$ \\
\hline
\end{tabular}

This article proposes that the task of Jesus' disciples could be to juxtapose new and old unconditional prophecies concerning the kingdom of heaven. Matthew 13 can be read as a prophetic discourse and specific, prophetic referents are identified to gain insight into the prophecies contained in these parables. From a pre-millennial perspective, the kingdom of heaven is seen to exist in terms of the New Covenant in a spiritual sense from the cross of Christ onwards, but it will also be established in a literal sense in terms of the Davidic Covenant when Christ returns. This article discusses the four parables of Matthew 13 that were presented in public.

'n Ondersoek na Matteus 13 as 'n profetiese diskoers: Die vier gelykenisse wat in die openbaar aangebied is. Hierdie artikel stel voor dat dit die taak van Jesus se dissipels sou kon wees om nuwe en ou onvoorwaardelike profesieë oor die koninkryk van die hemele met mekaar te vergelyk. Matteus 13 kan as 'n profetiese diskoers gelees word en spesifieke, profetiese referente word geïdentifiseer om die profesieë in hierdie gelykenisse te begryp. Vanuit'n pre-millenniale perspektief blyk dit dat die koninkryk van die hemele in 'n geestelike sin in terme van die Nuwe Verbond vanaf Christus se kruis en daarna bestaan, maar dit sal ook in 'n letterlike sin tot stand kom in terme van die Dawidiese Verbond wanneer Christus terugkeer. Hierdie artikel bespreek die vier gelykenisse van Matteus 13 wat in die openbaar aangebied is.

\section{Introduction}

Matthew 13 is still a battleground for interpreters (cf. Ryrie 2005:80). Even if commentators agree about what a parable is or what it may specifically mean, they may disagree about its eschatology. ${ }^{1}$ At least three major views exist about whether there are one or two phases to the kingdom of heaven. ${ }^{2}$ Even if they hold like-minded views about all the above, commentators may still differ about what the 'mysteries of the kingdom of heaven' are (cf. Mt 13:11). ${ }^{3}$ The words of Jesus Christ, however, will never pass away and the Lord requires every scribe instructed concerning the kingdom of heaven to understand 'all these things' and to bring forth what is 'new and old' (13:51-52; 24:35; NKJV). Even if there is agreement that 'all these things' refer to the parables and mysteries of the kingdom described in Matthew 13 (Carson 1995:331; Bailey 1999a:291), commentators disagree about what the 'new and old' may refer to. Amidst the plethora of proposed interpretations of the parables of Matthew 13, this article starts off by stating its theological presuppositions and research focus. Thereafter the parables of Matthew 13 are considered as a collective presentation ('all these things') and parabolic juxtaposition of unconditional 'new and old' prophecies regarding the kingdom of heaven. In this first article of a three-part series, the 'battleground' is the four parables in Matthew 13 presented in public. ${ }^{4}$

\section{Theological presuppositions and research focus}

The Messianic kingdom that the Messiah exclusively offers to the Jews in Matthew 4-12 (3:2; $4: 17$; 10:5-7; cf. 15:24) is not only a spiritual kingdom. In the early stages of his public ministry,

\footnotetext{
1.Davies and Allison (1991:381) observe that 'one wonders whether it is not a mistake to insist that all of the synoptic parables be approached with one method or with one set of fixed expectations as to what a parable must be'. Whilst proposing a methodology for interpreting the parables of Jesus, Van Eck (2009:8) even remarks that the 'classification of the parables is a modern construct, and is to be considered obsolete'. By 'eschatology' is meant the doctrine of the end things.

2.Even though there is agreement in parable scholarship that the kingdom is at the centre of Jesus' message, what Jesus meant by it 'is not a point of consensus' (Van Eck 2009:6). Proponents of 'realised eschatology' (Dodd 1953:51) think that Jesus' ministry realised
the kingdom of heaven, but that it exists only in the present, thus 'now-only'. Proponents of 'consistent eschatology' (Toussaint 1980:172) advocate that the kingdom of heaven has not been established and view the kingdom as future only, thus 'no, not yet'. Many scholars (Carson 1995:307; Blomberg 1990:297, 312) identify both a present and a future phase of the kingdom of heaven, the 'already-but-not-yet' view.
}

3.Further references to the Gospel of Matthew will be indicated only by chapters and verses.

4.The second article in this series considers the four parables in Matthew 13 that were presented in private (Scholtz 2015). 
'Jesus appears to be taking the Kingdom according to the eschatological root present in Judaism. His Kingdom is the reign of Yahweh manifested historically, politically, spiritually, and nationally' (Saucy 1997:329, 335). According to various Old Testament prophecies - see Is 32:15-20; Jr 31:31-34; Ezk 39:25-29; J1 2:28-3:1 and Zch 12:8-13:1 -'all Israel will be saved' and the Holy Spirit will be poured out over Israel immediately prior to the establishment of the Messianic kingdom (cf. Toussaint 1980:69). Many Jews living at the time of Christ's First Advent, however, thought they would automatically enter the kingdom simply because they were physical descendants of Abraham (3:9; cf. 8:12). Edersheim (1993) states:

$[N]$ o principle was more fully established in the popular conviction, than that all Israel had part in the world to come (Sanh 10.1), and this, specifically, because of their connection with Abraham. This appears not only from the New Testament (John 8:33, 39, 53), from Philo, and Josephus, but from many Rabbinic pages. 'The merits of the Fathers', is one of the commonest phrases in the mouth of the Rabbis. (p. 188)

Against the afore-mentioned Jewish misunderstanding that all Jews of all times automatically share in the age to come due to the merits of the fathers (cf. 3:7-10; 6:33; 8:11-12), the Lord insisted on a spiritual basis (or foundation) for the kingdom, but this does not abrogate the national, politicalgovernmental aspects of the kingdom of heaven. All Jews of that generation had to have repented by turning from their sins to God and accepting and trusting Jesus as the Messiah. Moreover, this generation of Jews also had to trust and accept the person that God anointed as the king of the Jews - as announced by 'more than a prophet' (Dt 17:14-15; Mt 3:13-17; 11:9-11; Johnson 1999:139-140). Therefore, if Israel 'will turn from their sins to God in anticipation of their Messiah' and if it will 'accept its King, Israel will have its kingdom' (Toussaint 1980:61, 138; cf. Fruchtenbaum 1989:615-617; Ryrie 2005:79-80), that is, the literal, earthly Davidic (or Messianic) kingdom would have been restored and established in terms of the Davidic Covenant. ${ }^{5}$

A turning point is reached in Matthew 11-12 when it becomes clear that, notwithstanding individual Jewish followers of Jesus, 'this generation' as a collective, national group refuses to put its house in order so that the Holy Spirit can be poured out over all Israel and the Messianic kingdom be established. When 'this generation' in Israel blasphemes the work of the Holy Spirit performed by the Son of David (12:22-45; cf. 23:36), the establishment of the kingdom in terms of the Davidic Covenant is postponed (12:23-45; Fruchtenbaum 1989:617; Toussaint, 1980:165). None of this 'surprised' God, for this development was part of God's plan (Fruchtenbaum 1989:611). Moreover, the nation of Israel is temporarily set aside as the vehicle through which God will accomplish his purposes on earth (cf. 12:46-50; 13:14-15). Until a future generation in the history of Israel accepts the

5.A more extensive discussion of the offer of the kingdom, the unpardonable sin and the Davidic Covenant is presented elsewhere (Scholtz 2014:3-5).
Lord Jesus Christ and Son of David (23:39; Allison 1983:77), the kingdom of heaven can exist only spiritually. ${ }^{6}$

The argument here is that, in terms of the New Covenant, the first, spiritual phase of the kingdom of heaven is proposed to commence with 'the complex of events including Jesus' death, resurrection, and the sending of the Spirit at Pentecost' (Blomberg 1992:187). Except for the parable of the sower, which includes a transitional component from the days of John and then onwards, most of the 'new' in the parables of Matthew 13 is viewed as prophetic relative to the day Jesus presents these parables $(13: 1,36,53)$. ' $\mathrm{New}^{\prime}$ truths regarding the first, spiritual phase of the kingdom of heaven are revealed, truths that were not directly predicted in the Old Testament (13:11-17, 35b). Holding to a pre-millennial perspective, this article sees the future phase of the kingdom of heaven (the 'not-yet' phase) to commence at Christ's Second Advent when the kingdom will literally be established in terms of the Davidic Covenant. ${ }^{7}$ Regarding the 'old' in these parables, this agrees with 'voluminous kingdom revelation of the Old Testament' (Beacham 1996:233). Perhaps surprisingly, the 'old' may refer to direct, unconditional prophesies about the establishment of the kingdom of heaven that will only be fulfilled during the Tribulation Period and at Christ's Second Advent - continuing into the future phase of the kingdom. ${ }^{8}$ Bailey (1999a) summarises the 'new and old' that the scribe must bring forth as follows: ${ }^{9}$

Israel's expectation of the coming earthly kingdom, as revealed in the Old Testament, needs to be taught along with the truths of the present interadvent age, the mystery element unknown in the Old Testament. The mysteries (the new element) of the kingdom present what God will do with His kingdom in the world apart from the nation of Israel. Later of course He will fulfil what $\mathrm{He}$ said He will do in the future through Israel. (p. 295)

In this article, the 'new and old' are therefore viewed as unconditional, predictive prophecies that will literally be fulfilled. ${ }^{10}$ According to Snodgrass (2008:22), the 'more a parable is a prophetic instrument the more we should expect the reality to show through'. As an Old Testament example, the moment the prophet Nathan tells David, 'You are the man!' (2 Sm 12:7), it becomes relatively easy to identify

6.Scholtz (2014:4) asks: 'Does Matthew's use of the term kingdom of heaven change after this generation's blasphemy of the Holy Spirit? If it did, one might logically expect Matthew to provide some explanation, but because none is given, the term kingdom of heaven is best interpreted as still referring to the messianic kingdom (cf. Beacham 1996:233; Toussaint 1980:173-176).

7.Pre-millennialism is that system of theology 'which holds that the second coming of Christ precedes the millennium' (Feinberg cited in Fruchtenbaum 1989:4).

8.The Tribulation Period is viewed from a pre-millennial perspective as a period of seven years immediately preceding the return of the Son of Man, comprising two consecutive periods of three and a half years each - the latter called 'the Great Tribulation' by Jesus (24:21; cf. Toussaint 1980:141).

9.Bailey (1999a:294) also argues what the new and old cannot be: "If any of the "old" is not yet fulfilled, there cannot be a wholesale setting aside of the old in favour of the new. Also the new cannot be a partial fulfilment of the promises of the old, because both, not just the new, is [sic] brought out of the treasure. Further, if the new simply fulfils the old, then it is really not new'.

10.The focus on the prophetic in this three-part series is not so much on forthtelling as it is on foretelling. Prophecies can either be symbolical (through words or acts) or typical (Tan 2000:71). The focus in the first two articles of the series is on prophecies contained or referred to in the parables of Matthew 13, which have prophecies contained or referred to in the parables of Matthew 13, which have
been, or will yet be, literally fulfilled. The third article of the series will focus on indirect prophecies that may be fulfilled typologically. 
specific, but in this case historical, referents for that parable. As a Matthean example, the sending of the sons of the kingdom into the world and not only to the lost sheep of the house of Israel is not only prophetical relative to the day Jesus spoke these parables, but the Son of Man is also a specific referent (10:5-7; 13:37-38; 15:24). Of course, not all parables are like this; the extent to which the details of a parable refer to persons, processes or events that will appear in history (that is, in the degree of specificity an analogy or a comparison makes) is debatable. Moreover, no one wants to be guilty of unbridled allegorising and be hit with Jülicher's allegorical stick. Then again, as Snodgrass (2008:33) points out, no one should 'reject a feature of Jesus' parables because it has allegorical significance. If Jesus' figures did not bear some relation to reality, he would have no reason to use them'. Focusing only on the parables of Matthew 13, this article accepts that Jesus used allegory as a literary device (but not as a hermeneutical move), requiring the decoding of details as exemplified in the parables of the sower, the tares of the field and the dragnet. If it is said, 'You are the allegorical man', note Blomberg's (1990) remarks about the Gospel interpretations of the parables of the sower and the tares of the field:

In each of these interpretations, almost all the major details of the parables are explained by means of a series of one-to-one correspondences.... Yet this is precisely the allegorical approach of the pre-modern era which has so roundly been rejected! (p. 17)

Not only can the parables of Matthew 13 include prophetic and specific content, but understanding the prophecies contained in these parables requires the identification of specific, prophetic referents. ${ }^{11} \mathrm{~A}$ person, process or event can be considered a specific, prophetic referent for both the 'new and old' of these parables if it is significant to God's kingdom and redemption purposes on earth.

Sider (1995:259; cf. Snodgrass 2008:9) argues that a parable 'expresses or implies the logic of analogy in the language of either simile or metaphor elaborated into a form of allegory that is selectively, but not pervasively, symbolic'. If parables use the logic of (proportional) analogy and if there are new and old prophecies regarding the kingdom of heaven that are juxtaposed, then the new and old must refer to unconditional prophecies. If the 'new and old' prophecies were merely conditional, one or both sides of the analogy could fall by the wayside, dragging the parable and its analogy down with it. ${ }^{12}$

Should one understand the parables of Matthew 13 as a

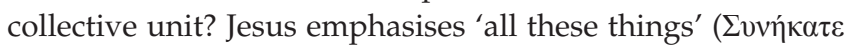
$\tau \alpha \tilde{\tau} \alpha \pi \alpha \dot{v} \tau \alpha$; 13:51) and Matthew is inspired to connect 'all these things' of the four parables spoken in public by the seaside (13:1-34) to the four parables spoken in private in

11. Moreover, the mysteries of the kingdom of heaven probably highlight specific truths aligned to God's redemption-kingdom plan and not what is general or mundane. Mysteries may refer to major turning points or even 'eschatological secrets' (cf. Davies \& Allison 1991:387-389; France 2007:508, 511; Hagner 2000:372, 390).

12.This seems to be true regardless of one's view of what the 'new and old' refer to. a house (13:36-52). Not only do these parables share the same immediate and larger context, they are undoubtedly presented as a thematic unit (cf. Blomberg 1990:113-114; Hagner 2000:392). Pentecost (1982:13) argues that identified referents in Matthew 13 may be used consistently when performing exegesis of the five unexplained parables of Matthew 13. Although making no such a priori assumption, if these parables contain new prophecies that do not contradict the old prophecies regarding the kingdom of heaven, then a measure of contextual consistency and coherence in this parabolic discourse is to be expected. As anyone who has solved a Rubik's cube or a large Sudoku puzzle can attest to, using referents (or clues) possibly in a contextually consistent way may assist in understanding individual parables, but simultaneously makes it more difficult to force preconceived ideas onto these parables of Matthew 13 as a collective unit. Kinnebrew (2010) summarises the case for viewing these parables collectively:

If one is to understand the meaning of any of these parables, he must understand 'all' of the parables. None of the parables should be considered as 'stand alone' creations. Rather, they are each an important piece of a grand mosaic. (p. 10)

This article proposes that every scribe who has been instructed about the kingdom of heaven is to juxtapose unconditional 'new' prophecies of the first, spiritual phase of the kingdom with unconditional 'old' prophecies of the future, literal phase of the kingdom of heaven. The 'old' includes prophecies that will be fulfilled during the Tribulation Period and at Christ's Second Advent, events that will usher in the establishment of the future, literal phase of the kingdom. What follows is not a detailed exegesis of the four parables of Matthew 13 presented in public, but a reading in accordance with the research focus of this article.

\section{The parable of the sower in Matthew}

The title of this parable emphasises not the soils, but the sower, it is 'the parable of the sower' (13:18). In Matthew's Gospel, God the Father is described as the Lord of the harvest and those sent to do his bidding are called labourers (9:38). Blomberg (1990:226; cf. Bailey 1998a:179) notes that the 'imagery of God as sower and the people of the world as various kinds of soil was standard in Jewish circles'. Thus, many commentators identify Jesus as the sower: 'The broader Matthean context, however, as well as 13.37 ("he who sows ... is the Son of man"), encourages one to think of Jesus' (Davies \& Allison 1991:399; cf. Ellisen 2001:87). After the risen Lord has received all authority in heaven and earth, the Son of Man sends labourer-disciples into 'his field', identified as the world (13:37-38; 28:18-20; cf. 11:27a). Those who preach the word of the kingdom are also labourer-sowers. Nevertheless, even though labourers are used in 'his harvest', God is the Lord of the harvest (9:38), Jesus is God (cf. 22:41-46) and therefore the ultimate and primary Sower in the kingdom of heaven is God. At all times when the word of the kingdom is preached, Jesus is significant to accomplish God's kingdom 
and redemption purposes on earth and therefore qualifies as a specific referent.

What is sown is identified as 'the word of the kingdom' (o $\lambda$ ó $\gamma o \varsigma$ $\tau \tilde{\Upsilon} \varsigma \beta \alpha \sigma 1 \lambda \varepsilon i \alpha \varsigma ; 13: 19)$. In agreement with Davies and Allison (1991:374), the leading theme of the kingdom of heaven and its reception 'comes up for treatment at this juncture in the gospel because of the rejection so far experienced by Jesus and his disciples'. The parable, however, not only looks back from the days of John the Baptist, it also looks ahead to future responses to the word of the kingdom, providing illustrations of faith in Jesus Christ, leading to discipleship (or lack thereof) and different levels of fruitfulness (or lack thereof). The 'word of the kingdom' includes preaching when the content of the gospel is the kingdom, which emphasises Christ and the nearness of the Davidic kingdom as well as when the content of the gospel emphasises the sign of the prophet Jonah, a thinly-veiled reference to Christ's death, burial and resurrection (Scholtz 2014:5). This introductory parable to the series consequently belongs to the first, spiritual phase of the kingdom, illustrating various 'soil'-responses and fruit-bearing (or lack thereof) to Jesus Christ and the word of the kingdom, be it during Christ's First Advent (through the gospel of the kingdom), during the great commission (through the gospel of Christ) or during the Tribulation Period (through the gospel of the kingdom). During all these times, trusting the word of the kingdom is a pre-condition before the mysteries of the kingdom are given to disciples, before more can be received (13:11-12; cf. Mk 4:13).

Patte (1987:184-187) identifies something 'new', namely that the disciples of Jesus receive understanding of the mysteries and a surplus of knowledge about the kingdom of heaven (the 'you' of 13:18). Old Testament prophets and righteous persons do not receive what the disciples of Jesus receive (13:11, 16-17), but they do have the 'old' prophecies. These 'old' prophecies relate to the establishment of the kingdom of heaven, to be fulfilled during the Tribulation Period or at Christ's Second Advent - continuing into the future phase of the kingdom of heaven.

\section{The parable of the tares of the field}

The parable of the tares of the field begins in an unusual way $(13: 24)$. It is likely that the parable begins at a specific point in time, indicating a marked historical development. Carson (1995; cf. Nolland 2005:544; Snodgrass 2008:212-213) writes:

\footnotetext{
The normal way for 'synoptic parables of the sort "the kingdom is

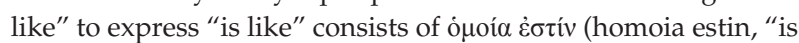
like") plus dative. In Matthew, however, this pattern sometimes

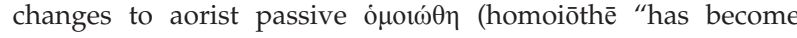

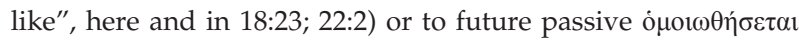
(homoiōthēsetai, "will become like," 7:24, 26; 25:1). (p. 317)
}

If the kingdom of heaven has become like the situation of a man who sowed good seed, et cetera, what has happened?

During Christ's First Advent the gospel was preached only in Israel $(10: 5-6 ; 13: 13-15 ; 15: 24)$, but in this parable the Son of Man sows good seed in 'his field', which is identified as the world (13:38), indicating a universal mission. Commenting on the statement that the field is the world', Carson (1995:325) says that it 'presupposes a mission beyond Israel (cf. 10:16-18; 28:18-20) and confirms that the narrower command of Matthew 10:5-6 is related exclusively to the Twelve during the period of Jesus' earthly ministry'. Hagner's (2000) comment is considered important:

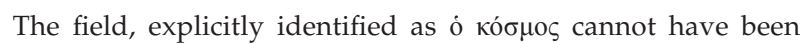
understood as the Church by the evangelist or his readers. This identification of the field as the world does, however, point in itself to the worldwide mission of the Church in the spread of the gospel ... (p. 393)

The fact that the disciples did not know of the great commission on the day Jesus tells this parable strongly suggests that Jesus is presenting a new prophecy given in the form of a parable juxtaposed with old prophecies regarding the kingdom of heaven.

The Son of Man sows 'good seed' that is specifically identified as 'sons of the kingdom' (13:38). Is it possible to identify the first 'sons of the kingdom' sown into the world by the Son of Man, and can the time when they were sown be identified? This is indeed possible. The 11 disciples fit the description of these first 'sons of the kingdom': they are the ones who meet Jesus at the mountain in Galilee and whom he then commands with all authority to commence the great commission (28:16-20; cf. 10:2-6). The sowing of these first 'sons of the kingdom' into the world by the Son of Man in terms of the great commission meets the criteria for specific, prophetic referents. Undoubtedly, the 'sowing' is significant as part of God's purpose in history to accomplish his kingdom and redemption programmes. When Jesus utters this parable, its content refers to the future. When Matthew writes the Gospel, the first part of the parable has already become history. However, the 'replacement' or 'second narrative' (Nolland 2005:559; Davies \& Allison 1991:429) of Matthew 13:40-43 still awaits its prophetic fulfilment at the end of this age.

The questions of the servants - 'Sir, did you not sow good seed in your field? How then does it have tares?' (13:27) are peculiar, implying that the servants expected the field to contain no tares. If unbelievers have been roaming the world since the days of John the Baptist, what set of circumstances allow for this implicit expectation? In view of the new development - the kingdom of heaven has become like (13:24) - and the connection between the question in the parable (13:27) and the judgment scene (13:40-43), what occasion prompts this parable?

The apostles and their fellow disciples have to learn that the first, spiritual or 'new' phase of the kingdom of heaven can begin to exist as the Church is baptised with the Holy Spirit. They also have to learn that this is not the same ministry as something 'old' that has previously been prophesied, namely the outpouring of the Holy Spirit on all Israel immediately 
before the establishment of the kingdom of heaven on earth. The Coming One can baptise with the Holy Spirit in terms of the New Covenant without the future phase of the kingdom of heaven having yet been established in terms of the Davidic Covenant. Moreover, the prophesied judgement immediately preceding the establishment of the Davidic kingdom has been delayed (13:40-42; cf. 3:7-12; 13:49-50). It has been delayed during a period that includes the Church Age, but judgement will commence during the Tribulation Period (22:44). Until that judgement, and since he is not yet bound, Satan has started a counterfeit sowing $(13: 25,38 b)$.

Since judgement is the prerogative of the Son of Man, believers are not responsible for separating the righteous from the wicked before that event at the end of the age (Bailey 1998b:276). The establishment of the Messianic kingdom will be preceded by judgement so that the field will have no tares (3:12; 13:40-43), for when a divine kingdom is established, it cannot be divided initially or ultimately, for a kingdom divided against itself cannot stand (12:25-26). If any rebellion against the will of God should manifest itself after the establishment of such a divine kingdom, the timing of any judgement on such rebellion depends on whether God extends a period of grace that allows for repentance or not. If grace is extended, rebellion may, in the interim, exist in a divine kingdom, but not initially or ultimately. It is submitted that since no such judgement has yet occurred, the Son of Man will thoroughly clean out his threshing floor at the end of this age, uproot the tares, and gather his wheat into the barn (13:29-30, 40-43; cf. 3:12). Once the kingdom has been established, the 'old' prophesies of Daniel 12:3 and Malachi 4:2 will be fulfilled, namely that the righteous will shine like the sun in the kingdom of their Father (cf. 13:43; cf. 17:2).

\section{The parable of the mustard seed}

Immediately after the parable of the tares of the field, the man sows a mustard seed, again in 'his field' (13:31). Since the authority given to the Lord Jesus after the cross has not changed (28:18), it is likely that 'his field' again refers to the world and the man who sows again refers to the Son of Man (cf. 13:37-38; Nolland 2005:552). In agreement with Luz (2001):

[R]eaders of Matthew have just come from the parable of the weeds. Since Jesus will not explain our parable, they will understand it in light of Jesus' explanation of the parable of the darnel. Therefore, they probably understand the 'person' who sows as the Son of Man and the 'field' as the world. (p. 262)

What does the Son of Man sow into the world? Although Jesus' other reference to a mustard seed in Matthew is about faith ('if you have faith as a grain of mustard seed'; 17:20), it is nevertheless people who exercise faith. Here one can venture that the mustard seed refers to a 'son of the kingdom', just as the good seed in Matthew 13:37-38 refer to persons, namely 'sons of the kingdom'. Also, there is little doubt that this mustard seed meets the criteria of proportion and indispensability emphasised by Snodgrass (2008:28) and Sider (1995:237-241), namely that the more prominent or central a feature of a parable is, the more likely it is to be symbolic, for if an element is required to make the story work, if it is so central or unusual, it may have symbolic significance. Moreover, Luz (2001:261) stresses that a single mustard seed was sown. If at least 500 mustard seeds weigh one gram, and this man sowed a single seed, Nolland's (2005) statement seems valid:

Since one would not normally consider sowing a single mustard seed, the singleness of the sowing is already an allegorical feature of the account. ... Given, however, that a specific occasion of sowing is in view, a better possibility is that the smallness relates specifically to a particularly chosen seed, not to mustard seeds in general. (pp. 550-551)

Who, then, did the Son of Man sow as a single mustard seed in the world? It is submitted that the mustard seed probably finds specific, prophetic reference in the apostle Peter. How can this view be motivated exegetically from Matthew? The Gospel of Matthew presents Peter as the first of the disciples to be called; Jesus heals Peter's mother-in-law; and Simon Peter is the first apostle amongst equals $(4: 18 ; 8: 14-15 ; 10: 2)$. As this Gospel continues, Peter rises in prominence, for he walks (and sinks) on water, acts as spokesman for the disciples, witnesses the transfiguration, and is with Jesus in Gethsemane (14:28-31; 15:15; 17:1-9; 18:21; 19:27; 26:36-46).

Of paramount importance, however, is the fact that God the Father reveals to Simon Peter that Jesus is the Christ, the Son of the living God (16:13-17; cf. 11:25-27). Although other disciples are also blessed with receiving divine revelation (13:11, 16-17), it is Simon Bar-Jonah whom Jesus specifically

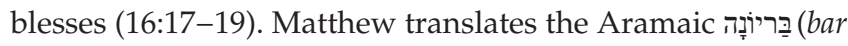

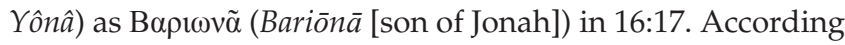
to France (2007), no obvious reason exists explaining why Matthew:

should have changed the name in order to associate Peter or his father with the biblical Jonah; it is Jesus, not Peter, who is 'greater than Jonah' (12:40-41), and the 'sign of Jonah' (12:39; 16:4) does not relate to Peter. (p. 620)

Perhaps there is a reason. This name may foreshadow that Jonah's mission to non-Jews would be repeated later by Peter (Wall 1987:79). Jesus can send a 'son of Jonah' to proclaim justice to the Gentiles, a ministry that will continue until One greater than Jonah sends forth justice to victory $(12: 18,20,41)$.

The rock on which Jesus will build his Church (16:18) is viewed variously (and sometimes polemically) as Peter, Jesus or the truth of Peter's statement. Commenting on 16:18, France (2007:622-623) points out that in the early chapters of Acts, Peter leads and takes the initiative in the key developments that will constitute the Church: 'note especially his role in the bringing in of Samaritans (Acts 8:14-25) and Gentiles (Acts $10: 1-11: 18 ; 15: 7-11)^{\prime}$.

Whereas the authority to bind and loosen is given to all the apostles (18:18), Jesus specifically gives the keys of the kingdom of heaven only to Peter (16:19). These keys confer the authority to open the door of the kingdom of heaven 
to Jews, Samaritans and Gentiles (28:18b-20; cf. 10:5-7; Toussaint 1980:205). Fruchtenbaum and Gendron (1996) describe Peter's special role in connection with the keys of the kingdom as follows:

Having the keys, already known from the Old Testament, carried two concepts: first, authority (Isa. 22:20-24) and, second, the right to unlock the door. Therefore, the basic point of Matthew 16:19 is that Jesus gives the authority to Peter to open the door of the church, or the body of Christ, to all three segments of humanity. Once he opens the door for a segment of humanity, it will remain open for them. This helps explain the sometime delay of the baptism of the Spirit to believers. (p. 230)

The teachings of 16:17-19 clearly show that God the Father and Jesus Christ intended Peter to have a unique, privileged role. The Lord of heaven and earth has hidden 'these things' and, if the least of these little children finds or identifies Christ, then the Head of the household blesses the child with a gift through the Son (16:16-19; cf. 11:25-27). It is a distinct possibility that the mustard seed may specifically and prophetically refer to the apostle Peter in his role as bearer of the keys of the kingdom of heaven to open the door, not only to Jews and Samaritans, but also to Gentile believers (cf. 10:5-6).

The parable describes 'the birds of the air' that find shelter in the tree. Manson (cited in Bailey 1998c:454-455) points out that the 'birds of heaven' are a stock symbol for Gentile nations, and Jeremias (1972:147) sees the tree in Matthew 13:32 as 'an eschatological technical term for the incorporation of the Gentiles into the people of God'. The allusion to the 'birds of the air' may have Gentiles in view as part of the kingdom of heaven as the great commission moves to all the nations of the world. ${ }^{13}$ However, this does not in any way downplay a focus on Jews or Samaritans. The argument here is that this tree does not refer to a Gentile kingdom or nation, but rather to the existence of the first, spiritual or 'new' phase of the kingdom of heaven via a ministry of the great commission (not with political or military power) extended to disciples of all nations, Gentiles included. Specific, prophetic referents identified include the Son of Man and the use of the keys of the kingdom by the apostle Peter as the great commission is extended to disciples of all nations.

The above must not be construed as agreement with the traditional Roman Catholic view that Peter was the first in a line of popes that exists to the present day. Once Peter exercised the authority to open the door of the kingdom of heaven, his role in this regard ceased. Peter does not provide salvation to anyone. Salvation is only by grace, through faith in Christ, who is the only High Priest according to the order of Melchizedek. The growth from a mustard seed to a tree is due to another mighty work of Christ, continuing to the present day, and could possibly be further explained in the parable of the leaven, which is placed immediately after the parable of the mustard seed.

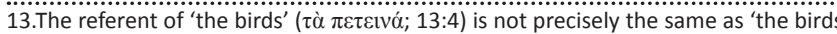
of the air' ( $\tau \dot{\alpha} \pi \varepsilon \tau \varepsilon i v \grave{\alpha} \tau o \tilde{v}$ ovj $\alpha$ voṽ; 13:32). Therefore, it does not seem inconsistent to understand 'the birds' of the parable of the sower differently from the 'birds of the air' in the parable of the mustard seed.
The 'new' in the parable of the mustard seed illustrates how the first, spiritual phase of the kingdom of heaven expands as the Son of Man authorises the apostle Peter to use the keys to open the door of the kingdom of heaven to various groups of believers, Gentiles included. During its future phase, the Davidic kingdom will again reach international proportions, as Bailey (1998c:455) explains: 'Ezekiel 17:22-23 is the closest parallel to Jesus' parable, since the tree there represents the people of God rather than a Gentile power. ... Like the tender cedar twig the restored kingdom will reach international proportions.'

\section{The parable of the leaven}

Bailey and Constable (1999:27-28) convincingly argue that if leaven is understood negatively in this parable and if the kingdom will continue 'till it was all leavened', the kingdom would ultimately be completely corrupted by evil. Since no divine kingdom can be completely corrupted by evil, the leaven in this parable must refer to good permeation. Therefore, the woman is not doing something evil when she puts leaven into three measures of flour until it is all

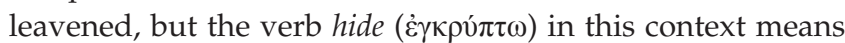
to 'put something into something' (Carson 1995:319). After Jesus in his humanity receives all authority in heaven and on earth, the Son of Man becomes the householder, and this woman is busy in the house $(13: 27 ; 28: 18)$. Moreover, 'the woman's action with the leaven must correspond to what is happening in Jesus' ministry' (Nolland 2005:554).

According to Davies and Allison (1991:423; cf. Jeremias 1972:147), the woman is not symbolic, but Jesus could have 'broken the bounds of actuality in order to make a point about God's supernatural kingdom'. The criterion of indispensability as noted previously may well be met again (cf. Snodgrass 2008:28; Sider 1995:237-241). Ellisen (2001:102) states that the leavening process stresses the inner source of power and growth as energised by the Holy Spirit. Bailey (1999b:70) likewise argues that the focus of the parable seems to be on how the leaven works inside the dough, picturing the Holy Spirit's work in the present age'. One can argue that the woman in the parable of the leaven may refer to the Holy Spirit.

If the woman's action with the leaven 'must correspond' to what is happening in Jesus' ministry, what ministry of the Holy Spirit specifically mentioned in Matthew and connected with the harvest and the barn may be in view (3:12; cf. 13:30, 39)? This ministry is in the future when John the Baptist prophesied about it and is still so at the end of this Gospel when Jesus commands his followers to make disciples of all nations. It is proposed that the prophecy about Christ baptising his followers with the Holy Spirit finds prophetic fulfilment during the period of the great commission when Jewish, Samaritan and Gentile believers (who are still not perfect, who still have leaven in their lives) are baptised into Christ by the Holy Spirit - until all has been leavened. During the Church age, the Holy Spirit is baptising believers into the body of Christ; he is 'putting something into something' (cf. Carson 1995:319). 
The central truth of the parable of the leaven may describe the unique ministry of baptism in or with the Holy Spirit to Jewish, Samaritan and Gentile believers during the first 'new' or spiritual phase of the kingdom of heaven in terms of the New Covenant. The Church age is included in this first phase. The unconditional 'old' prophecy that the Holy Spirit would be poured out over Israel immediately before the Messianic kingdom would be established in terms of the Davidic Covenant, will still be fulfilled. However, during all its phases, the existence, growth and establishment of the kingdom of heaven is due to the power of God.

\section{Conclusion}

Jesus may have juxtaposed unconditional new and old prophecies regarding the kingdom of heaven, explaining how this kingdom will exist spiritually even though the old prophecies regarding the establishment of the literal Davidic kingdom remain unfulfilled. Whereas the introductory parable of the sower may focus on Jesus' authority to have the word of the kingdom sown during this age in general, the next three parables presented in public may specifically focus on the time from Pentecost and onwards. Speaking indirectly in parables, because the Father has hidden Christ's mighty works from unbelievers $(11: 25 ; 13: 11,34)$, the Son of Man may prophetically have envisaged the day when he will command his 11 (later to become 12 again) apostles to commence the great commission, spearheaded by the single mustard seed. He may also have envisaged how the kingdom will grow as Jewish, Samaritan and also Gentile believers are baptised into Christ by the Holy Spirit in terms of the New Covenant. The growth of the kingdom of heaven during all its phases is the result of the power of God. Regarding the 'old' in these parables presented in public, they will be fulfilled at the appointed times set by the Father: towards the end of this age Elijah will return to restore all things and judgement will commence during the Tribulation Period immediately preceding the establishment of the kingdom of heaven (13:40-43; 17:11). All Israel will be saved, Christ will return to earth and, once the Davidic kingdom is established, it will grow like a tender twig into a majestic cedar, covering the entire earth in which birds of every sort will dwell (cf. Jr 31:31-34; Ezk 17:22-23).

\section{Acknowledgements Competing interests}

The author declares that he has no financial or personal relationship(s) that may have inappropriately influenced him in writing this article.

\section{References}

Allison, D.C., 1983, 'Matt. 23:39-Luke 13:35b as a conditional prophecy', Journal for the Study of the New Testament 18, 75-84. http://dx.doi org/10.1177/0142064X8300501803
Bailey, M.L., 1998a, 'The Parable of the Sower and the Soils', Bibliotheca Sacra 155(618), 172-188.

Bailey, M.L., 1998b, 'The Parable of the Tares', Bibliotheca Sacra 155(619), 266-279.

Bailey, M.L., 1998c, 'The Parable of the Mustard Seed', Bibliotheca Sacra 155(620), 449-459.

Bailey, M.L., 1999a, 'The Parables of the Dragnet and of the Householder', Bibliotheca Sacra 156(623), 282-296.

Bailey, M.L., 1999b, 'The Parable of the Leavening Process', Bibliotheca Sacra 156(621), 61-71.

Bailey, M.L. \& Constable, T.L., 1999, Nelson's New Testament survey, Thomas Nelson, Nashville.

Beacham, R.E., 1996, 'Parables of the kingdom', in M. Couch (ed.), Dictionary of Premillennial theology, pp. 231-234, Kregel Publications, Grand Rapids.

Blomberg, C.L., 1990, Interpreting the parables, IVP Academic, Downers Grove.

Blomberg, C.L., 1992, Matthew, The New American Commentary volume 22, B\&H Publishing Group, Nashville.

Carson, D.A., 1995, Matthew chapters 1 through 12 \& Matthew chapters 13 through 28 , Zondervan Publishing House, Grand Rapids. (The expositor's Bible commentary with the New International Version of the Holy Bible).

Davies, W.D. \& Allison, D.C., 1991, A critical and exegetical commentary on the Gospe according to Saint Matthew, T\&T Clark, Edinburgh. (The International Critical Commentary, 1, 2, 3)

Dodd, C.H., 1953, The parables of the kingdom, 3rd ed., Nisbet \& Co. Ltd, London.

Edersheim, A., 1993, The life and times of Jesus the Messiah: New updated version, Hendrickson Publishers, Peabody.

Ellisen, S.A., 2001, Parables in the eye of the storm, Kregel Publications, Grand Rapids.

France, R.T., 2007, The Gospel of Matthew, William B. Eerdmans Publishing Company, Grand Rapids.

Fruchtenbaum, A.G., 1989, Israelology: The missing link in systematic theology, Ariel Ministries, Tustin.

Fruchtenbaum, A.G. \& Gendron, M.P., 1996, 'Kingdom, keys of the', in M. Couch (ed.), Dictionary of Premillennial theology, pp. 229-230, Kregel Publications, Grand Rapids.

Hagner, D.A., 2000, Matthew 1-13, Thomas Nelson, Nashville. (WBC Commentary, 33A).

Johnson, E.E., 1999, 'Covenants in traditional dispensationalism', in H.W. Bateman (ed.), Three central issues in contemporary dispensationalism: A comparison of traditional and progressive views, pp. 121-168, Kregel Publications, Grand Rapids.

Jeremias, J., 1972, The parables of Jesus 3rd edition, SCM Press Ltd, London.

Kinnebrew, J.M., 2010, 'I love a mystery! Interpretive guidelines for the parables of Matthew 13', Journal of Biblical Ministry 2, 3-13.

Luz, U., 2001, Matthew 8-20: A commentary, ed. H. Koster, transl. J.E. Crouch, Augsburg Fortress, Minneapolis.

Nolland, J., 2005, The Gospel of Matthew: A commentary on the Greek text, William B. Eerdmans Publishing Company, Grand Rapids. (The New International Greek Testament commentary).

Patte, D., 1987, The Gospel according to Matthew: A structural commentary on Matthew's faith, Fortress Press, Philadelphia.

Pentecost, J.D., 1982, The parables of Jesus: Lessons in life from the Master Teacher, Kregel Publications, Grand Rapids.

Ryrie, C.C., 2005, The basis of the premillennial faith, ECS Ministries, Dubuque.

Saucy, M.R., 1997, The kingdom of God in the teaching of Jesus: In 20th century theology, Word Publishing, Dallas.

Scholtz, J.J., 2014, 'The kingdom of heaven and Matthew 10', In die Skriflig 48(1), Art. \#1782, 8 pages. http://dx.doi.org/10.4102/ids.v48i1.1782

Scholtz, J.J., 2015, 'Reading Matthew 13 as a prophetic discourse: The four parables presented in private', In die Skriflig 49(1), Art. \#1887. http://dx.doi.org/10.4102/ ids.v49i1.1887

Sider, J.W., 1995, Interpreting the parables: A hermeneutical guide to their meaning, Zondervan Publishing House, Grand Rapids.

Snodgrass, K.R., 2008, Stories with intent: A comprehensive guide to the parables of Jesus, William B. Eerdmans Publishing Company, Grand Rapids.

Tan, P.L., 2000, 'Symbols and types in prophecy', in M. Couch (ed.), An introduction to Classical Evangelical Hermeneutics: A guide to the history and practice of Biblical interpretation, pp. 71-86, Kregel Publications, Grand Rapids.

Toussaint, S.D., 1980, Behold the King: A study of Matthew, Kregel Publications, Grand Rapids.

Van Eck, E., 2009, 'Interpreting the parables of the Galilean Jesus: A social-scientific approach', HTS Teologiese Studies/Theological Studies 65(1), Art. \#308, 12 pages. http://dx.doi.org/10.4102/hts.v65i1.308

Wall, R.W., 1987, 'Peter, 'son' of Jonah: The conversion of Cornelius in the context of the canon', Journal for the Study of New Testament 29, 79-90. http://dx.doi. org/10.1177/0142064X8700902904 